\title{
Survey Practice Book List 2013
}

Mario Callegaro*

Tags: survey practice

\section{Survey Practice}

Vol. 6, Issue 1, 2013

Survey Practice Book List 2013

This article is an update of the April 2012 article. As the previous year, we organized the books by topics; this should help the readers to focus on their interests.

It is unlikely to list all new books in the field; we did our best scouting different resources and websites. The list is also focusing only on books published in the English language and available for purchase at the time of this review (March 2013). Books are listed based on the relevance to the topic and no judgment is made in terms of quality of the content. We let the reader do so. The journal section signals special issues of interest to Survey Practice readers. Finally, this year we started a thematic section with new books devoted to Infographics given the interest in the industry as a tool for visualizing data.

If you want to send information for the next issue, please send it to surveyprac tice.new.books@gmail.com

\section{JOURNAL NEWS}

The ANNALS of the American Academy of Political and Social Science published a special issue on "The nonresponse challenge to survey and statistics”. Volume 645, 1, 2013.

The Journal of Privacy and Confidentiality published a special issue on "Statistical and learning-theoretic challenges in data privacy". Volume 4, 1, 2012.

The Journal of The Royal Statistical Society, Series A, published a special collection of papers on "Paradata in social survey research". Volume 176, Part $1,2013$.

Social Psychology increased its frequency from 4 to 6 issues a year from 2013.

Frank Nolan, editor-in-chief of the Statistical Journal of the IAOS, passed away unexpectedly on October 16, 2012. Nolan was an internationally 
well-respected official statistician. He is been succeeded by Stephen Penneck, President, International Association of Official Statistics.

\section{NEW JOURNALS}

The Journal of Survey Statistics and Metbodology, sponsored by AAPOR and the American Statistical Association, will begin publishing in 2013. Its objective is to publish cutting edge scholarly articles on statistical and methodological issues for sample surveys, censuses, administrative record systems, and other related data. It aims to be the flagship journal for research on survey statistics and methodology. It is being published by Oxford University Press.

Political Science Research and Methods (PSRM) is a general political science journal dedicated to publishing original scholarly work of the highest quality from all subfields of political science. The journal specifically focuses on research applying rigorous methods to empirical or theoretical problems and promotes a rigorous scientific approach to the study of politics. PSRM welcomes work at the intersection of political science and related disciplines such as economics and sociology.

PSRM is the official journal of the European Political Science Association (EPSA) and strives to become one of the leading journals in political science. PSRM will publish two issues in 2013 and then three issues a year from 2014.

Stat is an innovative electronic journal for the rapid publication of novel and topical research results, publishing compact articles of the highest quality in all areas of statistical endeavor. Its purpose is to provide a means of rapid sharing of important new theoretical, methodological, and applied research. Stat is a joint venture between the International Statistical Institute and Wiley-Blackwell.

Stat is a scientific journal for the international community of statisticians, researchers, and practitioners in allied quantitative disciplines.

Survey Methods: Insights from the Field is a new online only journal that started its publication in 2013.

The goal of Survey Methods: Insights from the Field is to promote professional exchange on practical survey research issues and discussion on new and promising paths in survey research. The journal will be orientated toward the daily work of surveying, including questionnaire design, sampling, interviewer training, fieldwork administration, data preparation, documentation, and dissemination. The focus of the journal is on practical issues of survey research. The journal will be edited jointly by Swiss Foundation for Research in Social Sciences (FORS) and German Social Science Infrastructure Services (GESIS) and supported by an Editorial Board of approximately 20 colleagues. The review process will be performed with regard to topic, scientific and/or practical added value, style, grammar, and netiquette. 


\section{PUBLIC OPINION BOOKS}

Best, S.J. and B.S. Krueger. (Eds.). 2012. Exit polls: surveying the American electorate, 1927-2010. CQ Press, Los Angeles, CA.

Bucy, E.P. and R.L. Holbert. (Eds.). 2012. Sourcebook for political communication research: methods, measures, and analytical techniques. Routledge, New York.

Enns, P.K. and C. Wleizen. 2011. Who gets represented. Russell Sage, New York.

Erikson, R.S. and C. Wlezien. 2012. The timeline of presidential elections: how campaigns do (and do not) matter. University of Chicago Press, Chicago, IL.

Holtz-Bacha, C. and J. Stromback. (Eds.). 2012. Opinion polls and the media: reflecting and shaping public opinion. Palgrave Macmillan, New York.

\section{SURVEY METHODS BOOKS}

Abbott, M.L. and J. McKinney. 2013. Understanding and applying research design. Wiley, Chichester.

Alper, J., M.N. Feit and J.Q. Sanders. 2012. Collecting sexual orientation and gender identity data in electronic health records: workshop summary. National Academies Press, Washington DC.

Andres, L. 2012. Designing and doing survey research. Sage, Thousand Oaks, CA.

Bernard, H.R. 2013. Social research methods. Qualitative and quantitative approaches (2nd ed.). Sage, Chichester.

Blasius, J. and V. Thiessen. 2012. Assessing the quality of survey data. Sage, Chichester.

Bocarnea, M.C., R.A. Reynolds and J.D. Baker. (Eds.). 2012. Online instruments, data collection, and electronic measurements. IGI Global, Harrisburg, PA.

Bolger, N. and J.P Laurenceau. 2013. Intensive longitudinal methods: an introduction to diary and experience sampling research. Guilford, New York.

CNSTAT. 2013. Nonresponse in social science surveys: a research agenda. National Academies Press, Washington D.C.

Creswell, J.W. 2013. Research design: qualitative, quantitative, and mixed methods approaches (4thed.). Sage, Chichester.

Davino, C. and L. Fabbris. 2012. Survey data collection and integration. Springer, Berlin. 
Dillman, D.A. and C.C. House. (Eds.). 2012. Measuring what we spend: toward a new consumer expenditure survey. National Academies Press, Washington DC.

Edmonds, W.A. and T.D. Kennedy. 2013. An applied reference guide to research designs. Sage, Chichester.

Fink, A. 2013. How to conduct surveys: a step-by-step guide (5th ed.). Sage, Chichester.

Geisinger, K.F. 2013. APA bandbook of testing and assessment in psychology (Vols. 1-3). American Psychological Association, Washington DC.

Gideon, L. (Ed.). (2012). Handbook of survey methodology for the social sciences. Springer, New York.

Goodwin, J. 2012. SAGE secondary data analysis. Sage, Chichester.

Hine, C. 2013. Virtual research methods (Vols. 1-4). Sage, Chichester.

Hughes, J. 2012. SAGE internet research methods (Vols. 1-4). Sage, Chichester.

Kamberelis, G. and G. Dimitriadis. 2013. Focus groups: from structured interviews to collective conversations. Routledge, Milton Park, Oxon.

Miller, L.A., R.L. Lovier and S.A. McIntire. 2013. Foundations of psychological testing: a practical approach (4th ed.). Sage, Los Angeles, CA.

Nezlek, J.B. 2012. Diary methods. Sage, Chichester.

Ornstein, M. 2013. A companion to survey research. Sage, Chichester.

Salzborn, S., D. Eldad and J. Reinecke. (Eds.). 2012. Methods, theories, and empirical applications in the social sciences. Festschrift for Peter Schmidt. Springer, Berlin.

Walden, G.R. 2012. Focus group research. Wiley, Chichester.

\section{SURVEY STATISTICS BOOKS}

Alfres, V.R. 2012. Methods of randomization in experimental design. Sage, Chichester.

Andreß, H.-J., K. Golsch and A.W. Schmidt. 2013. Applied panel data analysis for economic and social surveys. Springer, Berlin.

Aneshensel, C.S. 2012. Theory-based data analysis for the social sciences (2nd ed.). Sage, Los Angeles, CA.

Chambers, R.L., D.G. Steel, D.G. Wang and A. Welsh. 2013. Maximum likelihood estimation for sample surveys. CRC Press, Boca Raton, FL.

Dunning, T. 2012. Natural experiments in the social sciences: a design-based 
approach. Cambridge University Press, Cambridge, UK.

Good, P. 2013. The A-Z of error-free research. CRC Press, Boca Raton, FL.

Hanneman, R., A.J. Kposowa and M.D. Riddle. 2012. Basic statistics for social research. Cambridge University Press, Hoboken, NJ.

Harring, J.R. and G.R. Hancock. 2012. Advances in longitudinal methods in the social and behavioral sciences. Information Age Publishing, Charlotte, NC.

Hubert, L. and H. Wainer. 2012. A statistical guide for the ethically perplexed. CRC Press, Boca Raton, FL.

Hundepool, A., J. Domingo-Ferrer, L. Franconi, S. Giessing, E.S. Nordholt, K. Spicer and P.-P. de Wolf. 2012. Statistical disclosure control. Wiley, Hoboken, NJ.

Kirk, R.E. 2013. Experimental design: procedures for the behavioral sciences (4thed.). Wiley, Chichester.

Kline, R.B. 2013. Beyond significance testing: statistics reform in the behavioral sciences (2nd ed.). American Psychological Association, Washington D.C.

Kohler, U. and F. Kreuter. 2012. Data analysis using Stata (3rd ed.). Stata Press, College Station, TX.

Mead, R., S.G. Gilmor and A. Mead. 2012. Statistical principles for the design of experiments. Applications to real experiments. Cambridge University Press, Cambridge, UK.

Newcombe, R.G. 2012. Confidence intervals for proportions and related measures of effect size. CRC Press, Boca Raton, FL.

Silver, N. 2012. The signal and the noise: why so many predictions fail but some don't. CRC Press, New York.

Thompson, S.K. 2012. Sampling (3rd ed.). Wiley, Hoboken, NJ.

Thyer, B.A. 2012. Quasi-experimental research design. Oxford University Press, Oxford.

\section{INFOGRAPHICS}

Lankow, J., J. Ritchie and R. Crooks. 2012. Infographics: the power of visual storytelling. Wiley, Hoboken, NJ.

Manger, S., T. Finke and S. Fichtel. (Eds.). 2012. Informotion: animated infographics. Die Gestalten Verlag, Berlin.

Rendgen, S. and J. Wiedemann. 2012. Information graphics. Taschen, Köln. 